Louisiana State University

LSU Digital Commons

Faculty Publications

Department of Oceanography \& Coastal

Sciences

8-25-2009

Doubt And The Values Of An Ignorance-Based World View For

Restoration: Coastal Louisiana Wetlands

\author{
R. Eugene Turner \\ euturne@Isu.edu
}

Follow this and additional works at: https://digitalcommons.Isu.edu/oceanography_coastal_pubs

Digitadrt of the Oceanography Commons

Commons

Network

Recommended Citation

Tưner, R. (2009). Doubt And The Values Of An Ignorance-Based World View For Restoration: Coastal

Louisiana Wetlands. https://doi.org/10.1007/s12237-009-9214-4

This Article is brought to you for free and open access by the Department of Oceanography \& Coastal Sciences at LSU Digital Commons. It has been accepted for inclusion in Faculty Publications by an authorized administrator of LSU Digital Commons. For more information, please contact ir@lsu.edu. 


\title{
Doubt and the Values of an Ignorance-Based World View for Restoration: Coastal Louisiana Wetlands
}

\author{
R. Eugene Turner
}

Received: 7 June 2009 /Revised: 26 July 2009 / Accepted: 6 August 2009/Published online: 25 August 2009

(C) Coastal and Estuarine Research Federation 2009

\begin{abstract}
Embracing doubt, a signature strength of science, is an essential core component of an ignorance-based-world view (IBWV) that assumes the areas of certainty are small relative to the large field of ignorance. The contrasting knowledge-based world view (KBWV) assumes that small and mostly insignificant knowledge gaps exist. When the KBWV is combined with a sense of urgency to "do something," then the intellectual landscape is flattened, the introduction of new ideas is impeded, monitoring and adaptive management is marginalized, risky behaviors continue, and social learning is restricted. The history of three coastal Louisiana land-uses (agricultural impoundment, marsh management, and dredging) is one of ignored and untested assumptions that might have provided a causeand-effect means to avoid catastrophic land losses-the result of a KBWV that remains the primary perspective of Louisiana's current coastal restoration and management program that includes river diversions and a proposed expansion of hurricane protection levees into wetlands. I argue from the pathology of results that willful adoption of an IBWV in the administration, management, and implementation of restoration will reduce the scale and diversity of significant missteps in the future, improve project
\end{abstract}

\footnotetext{
"Failure to suspend and test assumptions is the most surefire way to guarantee patterns of interaction that simply reinforce positions from the past. In this way, untested assumptions come to govern organizational actions, just as they undermine genuine attempts at collaboration." Senge et al. 2008, p. 257.
}

R. E. Turner $(\bowtie)$

Coastal Ecology Institute,

and Department of Oceanography and Coastal Sciences,

Louisiana State University,

Baton Rouge,

LA 70803, USA

e-mail: euturne@1su.edu efficiencies, and cause fewer unintended consequences that cannot (again) be retracted.

Keywords Ignorance Science $\cdot$ Wetland restoration . Louisiana

\section{Introduction}

A restoration scientist, manager, or citizen asks questions, perhaps in the form of a hypothesis, to reveal ignorance in a constructive way that answers might usefully address. When questions are asked with humility, then there is a healthy respect for ignorance and an acknowledgment of the possibility for incomplete knowledge or understanding. The values of embracing doubt with respect are, perhaps, easier seen in the hindsight than with foresight, and are applicable in ways that range from the personal to scientific. Here are some recent examples: (1) the worldwide financial collapse in 2008 continues to expose significant incorrect or unexamined assumptions about managing economic issues affecting billions of people; (2) the failure of the New Orleans flood protection levees in 2005 (for the sixth time in the last 100 years) - levees that were built and maintained under the supervision of professional engineers - revealed "dysfunctional relationships between federal and more local government" (p. xxv, Seed et al. 2006) that successfully resisted critical inquiry until after the catastrophe (Seed et al. 2006; United States House of Representatives 2006; Turner 2007); and (3) the size of cod stocks on Georges Bank were misjudged by the authoritative fisheries scientists, and the fisheries declined precipitously, as institutional pressures for conformity among scientists and management resulted in models applied that misrepresented reality (Finlayson 1994). 
A strength of science is not that practicing scientists are persuadably better human beings than others, but that the methods of science may subject theories, hypotheses, and facts to falsifiable tests. The practice of science, in other words, formally embraces doubt, although the practitioners are not immune to a tendency to avoid doubt. The history of science, in fact, is replete with examples of scientists paying too little attention to doubt, which hinders new discoveries (Barber 1961). Kuhn warned against irrationally constraining ignorance into comfortably defined concepts ("Scientific research is a strenuous and devoted attempt to force nature into the conceptual boxes supplied by professional education" (Kuhn 1987)), and these concepts became the baseline of the "paradigms shifts" he wrote about.

What follows is a comparison of two different perspectives about how well doubt and ignorance are embraced by restoration science and management, and an analysis of how the adoption of each perspective affects project administration and results. I address how one of these perspectives has significance to coastal wetland restoration because of its potential utility in making progress on socially relevant problem-solving and to avoid the introduction of unintended consequences. I use examples from Louisiana because Louisiana has nontrivial coastal wetland losses receiving significant attention from individuals and from private and governmental entities and because billions of dollars are being spent in the process. There is no guarantee that additional funds are forthcoming or even that there will be a net gain in coastal wetlands after expending much time, energy, and money. I start with a description of coastal land formation to understand the biogeophysical context of Louisiana's coastal wetland growth and maintenance. I then review the losses in the last 100 years and some reasons why that happened, discuss the financial commitments for restoration, and close with some recommendations to reduce the number and kinds of failures and to improve outcomes.

\section{Two Different World Views}

We can engage in restoration with a primary perspective that emphasizes either a knowledge-based world view (KBWV) or an ignorance-based world view (IBWV; Vitek and Jackson 2008). The meaning of "world view" here is the central outlook or perspective characterizing restoration science. The KBWV assumes that we know most of what is needed to be known, that knowledge is finite, and anticipates that finality can be achieved. Bacon and Descartes, for example, embraced a KBWV through reductionism and assumed that the expansion of knowledge would create a global Garden of Eden by virtue of fully informed technological advances applied to an unruly Nature. The KBWV is not so worried about what is not known but how to apply what is known in the right way. The IBWV, in contrast, emphasizes what we do not know, assumes that it is a large proportion of what might be known, and that there is much that will not be known. Further, the IBWV anticipates that the expansion of knowledge in multiple areas of inquiry introduces additional complexity, if only because of the unseen and unexplored interactions between areas, with the effect that ignorance increases exponentially. As the saying goes, "the more we learn, the more we learn that we understand less and less." The IBWV, therefore, actively seeks new knowledge. Wendell Berry (1982) reminds us that "Acting on the basis of ignorance, paradoxically, requires one to know things, remember things for instance, that failure is possible, that error is possible, that second chances are desirable." A strong recommendation, therefore, is to not risk everything on one restoration strategy.

My experience and that of others working at the interface of science and management is that the IBWV often has a trivial stature compared to the KBWV despite many written and oral statements of intentions saying otherwise. Monitoring and adaptive management are signature activities of a IBWV, for example, and are frequently missing from restoration programs or superficially folded into the feedback loops of adaptive management (Ralph and Poole 2003; Bernhardt et al. 2005). Adaptive management, however, is only a part of the IBWV. The IBWV permeates not only the practice of science and the management of restoration, but also the administration of both. The IBWV and KBWV perspectives have important differences that ripple through the administration of science to the practitioner (Table 1). The adoption of IBWV, for example, may increase tensions between inquiry and conclusion (Table 1). If risks are perceived to be small, then the administration will emphasize project implementation while simultaneously reducing efforts that might question an already agreedupon set of procedures and outcomes. If the outcomes are predetermined, then questions about the foundational assumptions are viewed as interruptions in the efficient flow of work going from project design to implementation, management becomes confused with administration, and communication between pools of expertise is reduced. As a result, a "command and control" and rigid "stove-pipe" hierarchy is created and enforced, and the turnover of personnel is done with a view to continue the status quo. Developing an "exit strategy" is not seen as being necessary because it is assumed that the project will succeed. Successful administration of the IBWV, in comparison, does not substitute administrative structure for chaos, but does allow for a "container" for new 
Table 1 A comparison of a knowledge-based world view (KBWV) and ignorance-based world view (IBWV) in science and management

\begin{tabular}{|c|c|c|}
\hline & KBWV & IBWV \\
\hline Outlook & $\begin{array}{l}\text { Knowledge is almost complete; } \\
\text { small fields of ignorance }\end{array}$ & $\begin{array}{l}\text { Working in a field of ignorance } \\
\text { with small fields of knowledge }\end{array}$ \\
\hline \multicolumn{3}{|c|}{ Consequential results } \\
\hline Risks & $\begin{array}{l}\text { Gaps in knowledge may exist and can be managed by } \\
\text { technical adjustments; risk averse }\end{array}$ & $\begin{array}{l}\text { Assume that fundamental fields of ignorance exist that may } \\
\text { yield alternative outcomes that are unwelcome or offer } \\
\text { improvements; embrace risks }\end{array}$ \\
\hline $\begin{array}{l}\text { Adaptive } \\
\text { management }\end{array}$ & Desirable, but not essential because risks are small & $\begin{array}{l}\text { Essential and drives monitoring and project goal definition, } \\
\text { because risks may be large }\end{array}$ \\
\hline \multirow[t]{5}{*}{ Administration } & $\begin{array}{l}\text { Because risks are perceived to be small, there is fealty to the } \\
\text { original project assumptions; and is authoritative because } \\
\text { asking questions detracts from project implementation }\end{array}$ & $\begin{array}{l}\text { Embrace questioning and accept shifting assumptions as they } \\
\text { arise; ready and willing to change/adapt sooner rather than } \\
\text { later }\end{array}$ \\
\hline & Management (implementation) confused with administration & Facilitative and deliberative \\
\hline & $\begin{array}{l}\text { Count, do not read; check boxes first, ask questions second, if } \\
\text { at all }\end{array}$ & $\begin{array}{l}\text { Make informed judgments; actively seek alternative } \\
\text { viewpoints }\end{array}$ \\
\hline & $\begin{array}{l}\text { "Stove-pipe" hierarchy of knowledge management and } \\
\text { distribution }\end{array}$ & $\begin{array}{l}\text { Formal and informal cross-unit collaboration is expected and } \\
\text { encouraged }\end{array}$ \\
\hline & Tribal and hereditary to maintain continuity of mission & Controlled chaos; create permeable barriers for change \\
\hline $\begin{array}{l}\text { Decision } \\
\text { making } \\
\text { priorities }\end{array}$ & $\begin{array}{l}\text { Consensus }(100 \%) \text { to the extent that consideration of } \\
\text { alternatives is minimized }\end{array}$ & $\begin{array}{l}\text { Informed of all viewpoints; alternatives sought out without } \\
\text { negative consequences; }\end{array}$ \\
\hline
\end{tabular}

information and approaches, and alternative views are allowed or encouraged to enter the decision-making stream at all stages of the project. In addition, the very size of projects influences how well new or previously ignored information enters the social structure. Compared to small projects, for example, larger projects have more diverse and complex administrative and managerial challenges, which have the effect of raising social maintenance costs and lowering acceptance of new ideas (Peterson 1993).

The example used to examine these two views is the recent history of the Louisiana coastal zone. A brief background about the formation of the coast is given to frame a discussion about wetland-loss rates and restoration (with an emphasis on river diversions), which is succeeded by arguments making the case that embracing the IBWV has significant and positive consequences for restoration.

\section{Louisiana Coastal Land Formation}

The present-day Louisiana coastal zone (Fig. 1) began to form when the rise in sea level slowed about 7,000 years ago (Stanley and Warne 1994). The main course of the lower Mississippi River shifted six times as it found a shorter route to the sea (Fisk et al. 1954). This process of individual delta growth and abandonment continued until the modern bird-foot (Balize) delta formed about 200 years ago. The $17,417 \mathrm{~km}^{2}$ of coastal lands present in 1955 (Baumann and Turner 1990) accumulated at an average long-term rate of about $2.5 \mathrm{~km}^{2}$ year ${ }^{-1}$ for the whole coast. The Atchafalaya River (comprised mostly of diverted Mississippi River flow near St. Francisville, LA, and the Red River) discharges about one third of the Mississippi River into the Atachafalaya Bay near Morgan City. The land gain in the new Atchafalaya delta and Wax Lake outlet from 1950 to 1994 was about $4.2 \mathrm{~km}^{2}$ year ${ }^{-1}$ (Roberts et al. 2003), but about half was lost from 2004 to 2006 (Barras 2006). The Chenier Plain in western Louisiana has about $21 \%$ of the coastal wetlands in Louisiana. The southern half of these western LA wetlands are mostly on mineral sediments accumulating from the westward drift of the entrained abandoned deltaic sediments and storm/hurricane overwash. A series of separate shore-parallel to shoreoblique ridges of shell and sand is separated by progradational mudflats, wetlands, or open water.

The seaward progression of the deltaic plain occurred in stages to form sub-delta sediments that may be up to $14 \mathrm{~m}$ deep and overlay previously deposited deltaic inorganic sediments. The complete set of delta sequences may be $150 \mathrm{~m}$ thick. The delta mud is overlain by silts and sands and topped by deltaic sediments, including organic deposits (Fisk et al. 1954). When the water is shallow enough, however, emergent wetland plants become rooted in the inorganic sediments and the quantity and quality of soils accumulating changes dramatically. This is an abrupt ecological change that introduces a new way for soils to accumulate. Wetlands between distributary levees have an organic-rich soil (Frazier 1967), whose inorganic volume is 
Fig. 1 The Louisiana coastal zone. A The deltaic plain. $M R$ Mississippi River; $B M, D F$, and $T P$ are former agricultural impoundments (Big Mar, Delta Farms, and The Pen, respectively). $D P$ Davis Pond diversion. The Caernarvon diversion enters into BM from the north. B A natural channel and a dredged canal; the canal is about 25 $30 \mathrm{~m}$ wide. A spoil bank $(S B)$ encloses a canal. C The Golden Meadow oilfield (GMOF) west of the flood protection levee for the city of Golden Meadow. D An oil drilling rig at work in Terrebonne Parish
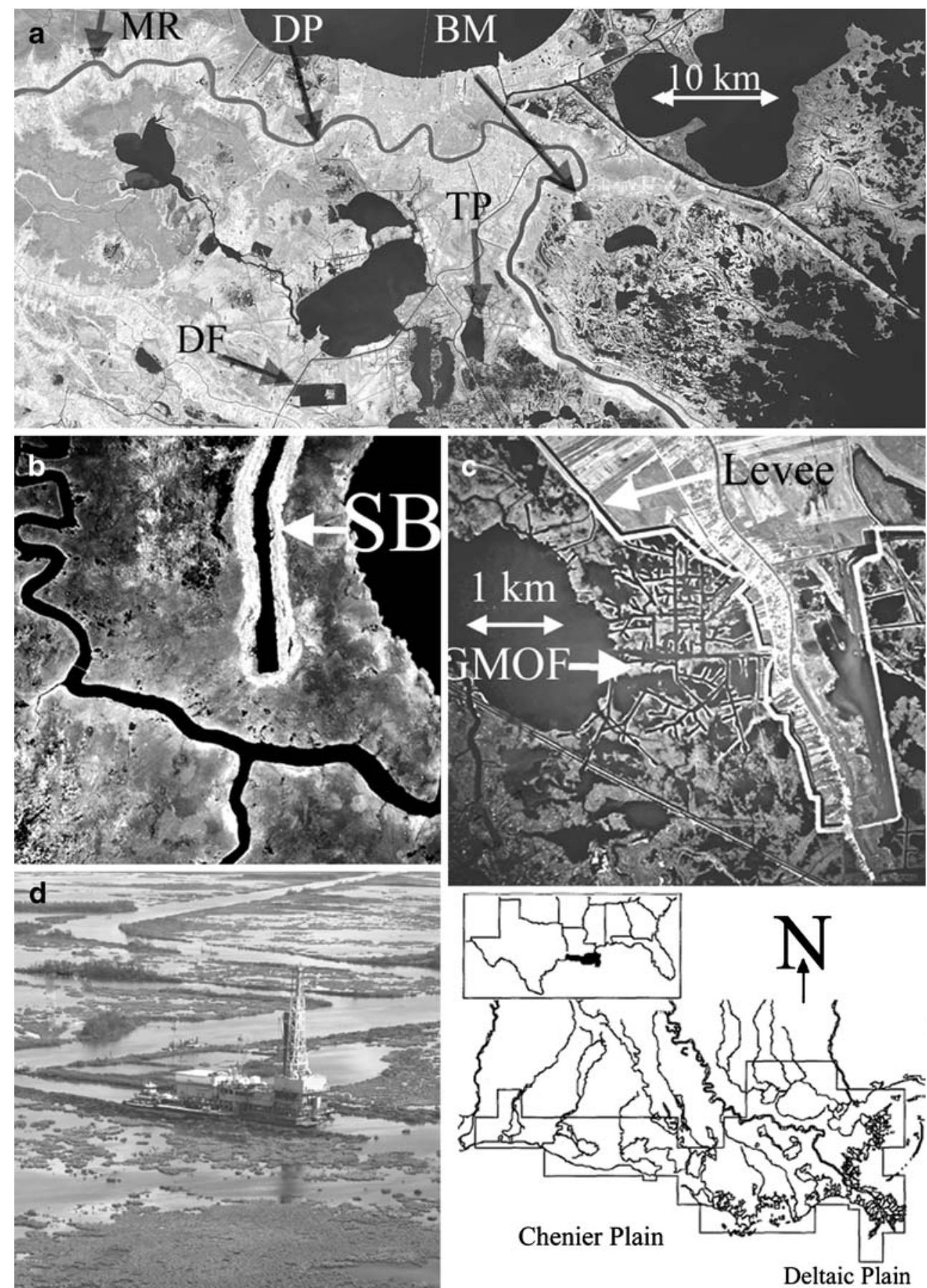

about $5 \%$ in salt wetlands and nearly zero in freshwater wetlands. The vertical accretion of wetland soils in these interdistributary wetlands is almost entirely dependent on the organic accumulation - a balance of belowground production and organic decomposition (Turner et al. 2001, 2007a). The accumulating fine-grained and highly organic sediments consolidate, compact, and oxidize, resulting in soil subsidence. The highest subsidence rates occur in the upper $2 \mathrm{~m}$ of the wetland soils that have an age of $<1,000$ years (Turner 2004; Turner et al. 2006b). Today's living plant has roots that penetrate up to $1 \mathrm{~m}$ belowground and, therefore, a minimal biochemical presence in soils originally formed $>500$ years BP.

The Mississippi and Atchafalaya river deltas have soils on the advancing edge that is mostly composed of inorganic, not organic, sediment. The early maps of European explorers (pre-1850s) show a Mississippi River delta mouth that was a multichannel network of thin overbank levees and an area of wetlands approximately the width of the main channel. European style inhabitation 
in the watershed in the early 1800 s was accompanied by enhanced sediment delivery to the coastal zone as trees were cut down and soils plowed (Turner and Rabalais 2003). The wetlands at the delta mouth, growing on highly inorganic soils, began to expand shortly thereafter. Dam construction of the post-1950s trapped sediments thereby reducing sediment delivery downstream by half (Meade and Parker 1984), after which the rivermouth wetlands receded.

Explosive breaks in flood protection levees, called a crevasse, are recognized by geomorphologists as being a different kind of overbank flooding than what occurred before flood protection levees existed. Before manmade levees, the sediment overflowing its banks accumulated near the river to form a levee parallel to the river channel that was not much wider than the river (Frazier 1967). The explosive release of floodwater through flood protection levees sent sediments further away from the river levee and sometimes formed a mini-delta (splay). Kesel (1988) estimated that the amount flowing overbank in the unconfined river was $4.8 \times 10^{6}$ and $1.8 \times 10^{6} \mathrm{mt} \mathrm{year}^{-1}$ through the flood protection levees (equal to $2.3 \%$ and $0.86 \%$ of the river's sediments, respectively; Table 2). While this is a large amount of sediment, the sediments introduced to wetlands during hurricanes may be as much as five times larger than from overbank sources before flood protection levees on the main channel and equal to about $12 \%$ of the river's annual sediment load (Table 2). Further, hurricanes may deliver 225 times more inorganic sediment than the largest river diversion (Caernarvon) and 14 times more than from crevasses through the constructed river levees (Table 2). These results may seem surprising if one thinks that the wetland soils are primarily dependent on mineral sediment supplied directly from the river by way of overbank flooding. Consider, however, that the wetlands in the Chenier Plain, the Terrebonne estuary, around Lake Pontchartrain, and in eastern Breton Sound have survived for thousands of years even though they are far from the Mississippi River. Further, the majority of coastal wetland soils are comprised of organic matter, not inorganic matter, and the inorganic soils are primarily found at the birds foot delta and within a few kilometers of land (Chabreck 1972).

\section{Land Loss, Human Interventions, and the IBWV}

The restoration on this coast is about the land lost since the 1930s, most of which was wetlands. Maps made before the 1930s delineated land between navigable waterways but did not show all the details about ponds and streams. Access to reliable coast-wide aerial photos, which began in the 1930s, meant that it was possible to reliably measure changes in land cover. The earliest aerial photographs showed vast expanses of wetlands (equal to $85 \%$ of the total land area; Baumann and Turner 1990) and an interwoven network of natural channels. The $3,954 \mathrm{~km}^{2}$ of land converting to open water between the 1930s and 1990 equaled the area of Rhode Island and was about $18 \%$ of the coastal land present in the 1930s (Britsch and Dunbar 1993). Thirtypercent of this land loss occurred in the Chenier Plain. The coastwide land-loss rate reached a peak in the 1960s and was on a trajectory to be near zero in the last 10 years (Fig. 2a), until the 2005 Hurricanes Katrina and Rita resulted in about $513 \mathrm{~km}^{2}$ of land converting to open water (Barras 2006). Some of this new open water area will convert back to wetland without intervention as it has before (Chabrek and Palmisano 1973). It would take more than 200 years at the 7,000-year net growth rate of $2.5 \mathrm{~km}^{2}$ year $^{-1}$, however, to compensate for this recent loss from hurricanes. Because hurricanes with a storm surge the size of hurricanes Katrina and Rita occur every 7.8 years (Turner et al. 2006a), it makes little sense to conclude that this coast could sustain a similar amount of wetland loss from hurricanes over the last 7,000 years. The 2005 land losses, in other words, were likely to be the result of an especially noteworthy synergism of effects involving a post-1900 land use change. Sea level rise is an unlikely synergistic agent, because there is no evidence (yet) that sea level rise has accelerated over the last 100 years (Turner 1991).
Table 2 Estimates of the sediment sources for the Mississippi River deltaic plain (adapted from Turner et al. 2006a)

\begin{tabular}{llc}
\hline \multicolumn{2}{l}{ Sediment source pathways } & Amount $\left(10^{6} \mathrm{mtyear}^{-1}\right)$ \\
\hline $\begin{array}{l}\text { Mississippi River discharge into ocean } \\
\text { One hurricane every } 7.9 \text { years }\end{array}$ & Onto wetland only & 210 \\
& Onto wetland and into open water & 8.3 \\
Overbank flooding (before flood protection levees) and into open water & 25.9 \\
Crevasses through levees and into open water & 4.79 \\
Caernarvon diversion & Into the estuary & 1.81 \\
& Onto wetlands & 0.115 \\
\end{tabular}



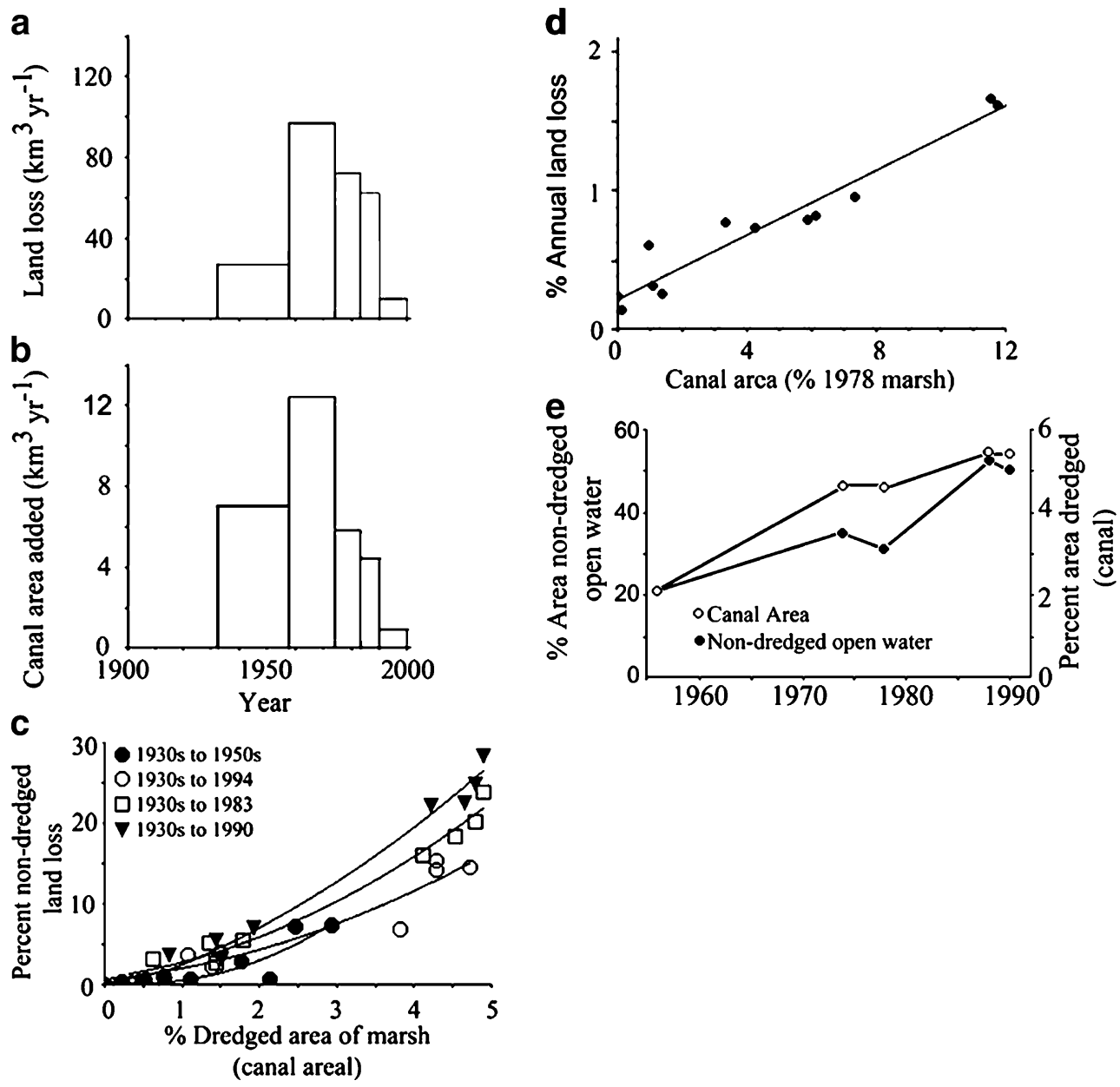

Fig. 2 Relationships between land loss and canal density in the Louisiana coastal zone. A The area of land loss for six intervals (adapted from Turner et al. 2007a). B The area of new canal added for six intervals (adapted from Turner et al. 2007a). C The relationship between direct land loss and indirect land loss (primarily canal density) in the Barataria watershed for eight 15-ft quadrangle maps were analyzed by Britsch and Dunbar (1993). No data were excluded. Four different mapping intervals are compared: 1930 s to $1950 \mathrm{~s}, 1930 \mathrm{~s}$ to 1950 s, 1930s to 1974 , and 1930 s to 1990 . Top Area of direct land loss vs. area of indirect land loss (ha). A linear regression of the data is

Three significant human interventions in the 1900s modified Louisiana wetlands in significant ways that might be done differently with the benefit of hindsight: agricultural impoundments, wetland management, and dredging.

\section{Agricultural Impoundments}

Wetlands were converted to agricultural fields throughout coastal North America as a continuation of land reclamations going back to Roman occupation of coastal Europe, if not earlier (Allen and Fulford 1992). Agricultural impoundments extended across the Louisiana coastal zone a century ago (Okey 1918) and amounted to about $452 \mathrm{~km}^{2}$ by 1915 (Turner and Streever 2002). This expansion of agriculture

shown ( $p<0.01$ in all cases). D Land-loss rates from 1955/1956 to 1978 in 7.5-ft quadrangle maps selected because they include the geologically defined St. Bernard delta complex, which underlies part of the modern day Barataria watershed (adapted from Scaife et al. 1983). A simple linear regression of the data is shown. The intercept is the same as what would be expected based on the lifetime of the St. Bernard delta (ca. 3,000 years old). E The percent nondredge open water and percent canal area versus year for salt marsh sites in Barataria estuary (adapted from Bass and Turner 1997)

into wetlands did not anticipate that acid sulfate soils would develop or that levee failures would lead to catastrophic collapse of the enterprise (Harrison and Kollmorgen 1947). The northern half of the Delta Farms impoundment failed sometime after 1915, when Okey (1918) documented its existence, because aerial photographs taken in 1930 show it as a wetland. The remaining $28 \mathrm{~km}^{2}$ Delta Farms impoundment collapsed in the 1960s when its levees failed during a storm, stranding equipment, and drowning livestock. It is now mostly open water. The open water of the Big Mar agricultural impoundment on the east bank of the Mississippi River receives the discharge from the Caernarvon diversion. All of the other former impoundments are either open water or are within an urban zone 
protected by flood protection levees (Turner and Streever 2002).

\section{Dredging}

Dredging navigation routes through Louisiana's coastal wetlands began at least 200 years ago (Davis 1973), but it was the canals dredged for oil and gas recovery efforts that began in the 1930s and that peaked in the 1960s (Fig. 2b) that had demonstrable and coastwide influences on wetlands. The direct impact of dredging on wetlands amounted to $1,017 \mathrm{~km}^{2}$ of canals in 1990 (Britsch and Dunbar 1993), and an equal area of spoil banks stacked on the adjacent wetlands (Baumann and Turner 1990). There is a much larger indirect impact from canals and the dredged spoil deposits that is demonstrable at several temporal and spatial scales. For example, (1) land-loss rates in the deltaic plain, in similar geological substrates, are directly related to dredging (Fig. 2c); (2) the amount of land loss where dredging is low is near zero (Fig. 2c, d); and (3) the landloss rates accelerated and slowed when dredging rose and slowed in the Barataria basin (Fig. 2e). If other factors were important influences on the empirically defined relationships between dredging and land loss, then the intercept of a linear regression between them would be zero or the data distribution would be statistically insignificant, e.g., noise. There are plausible cause-and-effect explanations for these relationships that are related to the loss of the accumulated organic matter and plant stress accompanying an altered hydrology (Swenson and Turner 1987; Turner 1997; 2004). The rise and fall in dredging is coincidental with the rise and fall of wetland loss (Fig. 2a, b), but sea level rise, soil subsidence, and the concentration of suspended sediment in the river have remained about the same from the 1960s to present (Turner 1991; Turner and Rabalais 2003). These results support the conclusion that the dominant cause of wetland loss on this coast is the result of dredging authorized in permits issued by State and Federal agencies. One would hope that the permitting process today would be more restrictive to prevent the foreseeable consequences of dredging these canals and creating spoil banks. But the damage was largely done by the time critical analyses were completed. Even today, there is no coastwide restoration program that specifically targets the direct and indirect impacts of canals and spoil banks on land loss. There is, despite several attempts to acquire it from the appropriate State agency, no publicly available annual estimate of the area of canals dredged from 2000 to 2007.

\section{Wetland Management}

Since the late $1930 \mathrm{~s}$, the hydrology of at least $3,440 \mathrm{~km}^{2}$ of Louisiana's coastal wetlands and open waters were man- aged through the use of pumps, weirs, flap gates, and culverts inserted into manmade levees (Boyer 1997). These structures are expensive to build and maintain. A metaanalysis of the literature, consisting of mostly unpublished graduate theses, was conducted to determine if weirs controlled salinity, enhanced vegetation cover, or improved wildlife habitat in ways that were consistent with the goals of marsh management. The conclusions were that, compared to the reference marshes, (1) weirs had little or no influence on salinity, (2) emergent plant cover was sometimes reduced behind the weirs, and (3) soil conditions suitable for maintaining wetlands were more stressful to the plants (Turner et al. 1989). The density of some wildlife species was similar or lower behind the weirs. The population size of some migratory waterfowl, however, increased behind the weirs because of the increased amounts of submerged macrophytes. Similarly, Boyer (1997) noted that there was no reduction in land-loss rates as a result of marsh management. In effect, the decadeslong implementation of marsh management, done for a variety of reasons besides the mitigation of land loss, was found to be causally related to increased land loss or was of no benefit. There were no new marsh management plans permitted in the last 5 years, and only wildlife agencies have active and large-scale maintenance of water control structures.

These three generic examples of coastwide land-use practices described above assumed the KBWV, not the IBWV. The area of the three interventions (exclusive of indirect impacts) ranges from $11 \%$ to $87 \%$ of the land area lost from the 1930s to 1990 (Fig. 3). These three large-scale examples were undertaken in support of goals whose supportive assumptions had not been tested before the wetland manipulation was complete and were not monitored before most were built, if at all. All three failed to conserve wetlands, and the open water created has not been restored to emergent wetland vegetation.

\section{Restoring Louisiana's Wetlands in a Field of Ignorance}

The largest present-day intervention in these wetlands is an effort to reduce land-loss rates or to restore wetlands. There are a variety of funding instruments, but the largest is the Coastal Wetland Protection and Restoration Act program (CWPPRA) that was initiated in 1991. The total amount for CWPPRA projects that were authorized, spent, or in design phase from 1991 to 2006 is $\$ 1.77$ billion (US Government Accountability Office 2007). The total area of the estimated "benefits" is about three times the area of actual land created or restored. The CWPPRA, for example, formerly issued estimates of the land created + restored of the total area 


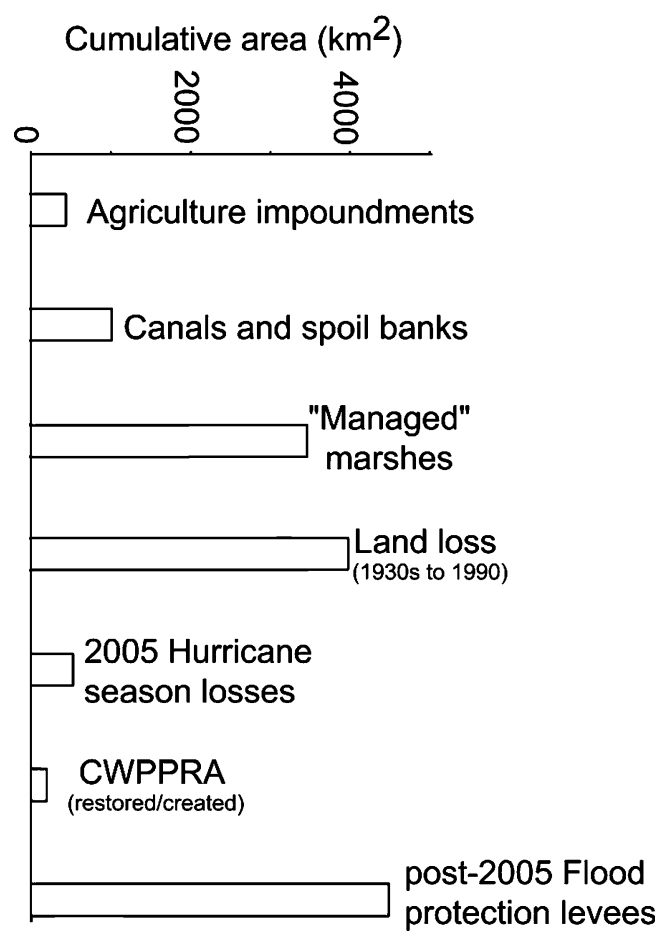

Fig. 3 The area of coastal wetland interventions in Louisiana and land losses (from top to bottom): Water area created as a result of agricultural impoundments (Turner and Streever 2002); canal and spoil banks formed from dredging (the area of spoil banks equals 1.2 times the area of canal water surface (Baumann and Turner 1990; Britsch and Dunbar 1993)); area affected by marsh management (pond, streams, and bayous surface area is included in the estimate (Boyer 1997)); net coastal land loss from 1930s to 2001 (Britsch and Dunbar 1993), land to water conversions occurring during the 2005 hurricane season (Barras 2006); the anticipated area of wetland creation and restoration from the CWPPRA program $35 \%$ of the area affected will be created and restored wetlands and that all projects will be $100 \%$ successful; the first 57 projects had 46 with an estimate of the created or restored acreage of the total. The average of 46 projects was that $35 \%$ of the area "benefited" would be restored (Anon 1995). The cost would be $\$ 295,857 \mathrm{ha}^{-1}$, at 2006 dollars, using these numbers (Anon 1995; US Government Accountability Office 2007)); and the wetlands affected by the proposed 100-year hurricane protection levees collectively known as "Morganza to the Gulf" (http://www.mvn.usace.army.mil/prj/mtog/ accessed 30 May 2009)

benefited that amounted to 35\% from 1991 to 1995 (Anon 1995). If we assume that: (1) all 2007 projects in the design and engineering phase will be successful and (2) the percent of created + restored area of the total project area is $35 \%$, then the average cost of the area restored and created after 20 years of project implementation will be $\$ 179,087 \mathrm{ha}^{-1}$ (2007 dollars). At this rate of expenditures, it would take about $\$ 71$ billion to restore all of the land lost from the 1930s to 1990. In comparison, this amount of money would fund the Department of Homeland Security, the US Department of Agriculture, or the National Science Foundation for $0.76,1$, or 12 years, respectively. These are clearly significant dollar expenditures.
The total land area hoped to be gained from of all CWPPRA projects, calculated at the same $35 \%$ rate, and occurring over the 20 year project lifetime equals $9.1 \mathrm{~km}^{2}$ year $^{-1}$ and is equivalent to 3.7 times the historical rate of land formation over 7,000 years. A comparison of the long-term wetland accumulation, the recent losses, the restoration efforts, and the losses after the 2005 hurricanes (Fig. 3) makes it quite clear that the current restoration efforts are grossly insufficient to restore the coast to the area present in the 1930s. Further, additional wetlands will be impounded, or semi-impounded, if the hurricane flood protection levees proposed after the 2005 hurricanes Katrina and Rita are built. The proposed levee system, known as the "Morganza to the Gulf," is estimated to be high enough $(5 \mathrm{~m})$ to not be topped by a 100-year storm event and is designed to have 13 tidal exchange structures within $116 \mathrm{~km}$ of earthen levee (the "Leaky Levee" concept). The area of salt and fresh water marshes influenced by the projected, either negatively or positively, is $4,400 \mathrm{~km}^{2}$ (http://www. mvn.usace.army.mil/prj/mtog/ accessed 30 May, 2009). If implemented, then it will be the largest intervention into wetland health on this coast to date (Fig. 3) and equal to 20 times more area than the CWPPRA restoration program, if successful.

\section{River Diversions}

Are the same mistakes being repeated again by adopting the KBWV instead of the IBWV? I think that we may be doing just that and will use the example of a major restoration tool, large river diversions, to discuss how significant questions remain concerning the current approaches that might have been addressed before several expensive river diversions were planned or undertaken. The answers to these questions may eventually support the assumptions about why diversions should be built. Alternatively, the answers may reveal either fatal flaws or significant insights on how to improve upon the performance of diversions. We should not be shy about asking questions. Stuart Pimm, an eminent ecologist, for example, told a story about Robert MacArthur, the "father" of island biogeography, in which he said: "There are worse things than being wrong, and being trivial is one of them."

The two largest diversions in Louisiana, the Davis Pond, and Caernarvon river diversions, are capable of delivering about 300 and $227 \mathrm{~m}^{3} \mathrm{~s}^{-1}$ of river water, respectively, to the adjacent estuary. Several smaller diversions are also operating. The reasons for diverting riverwater into wetlands rest on three goals (Anon 2006): (1) to reduce estuarine salinity, (2) to add sediments, and (3) to add nutrients. Whether these goals had a quantitative impact on land-loss rates was not vetted in the scientific literature before the diversions were built and are discussed next. 
Salinity

The only legal operational goal of the two largest river diversions is to control estuarine salinity. This goal evolved from the original purpose of the two largest diversions, which was based on the idea that oyster harvests would be improved if estuarine salinity was reduced. This hypothesis is contradicted by an analysis of oyster harvests in all of the major estuaries in the Gulf of Mexico (Turner 2006, 2008). The purpose of diversions had shifted, however, to also include the new assumption that lowering estuarine salinity, and stabilizing it (control) would reduce stressors on wetland plant health or even restore some wetlands. Part of the logic is that salinity intrusion kills plants to form open water habitat. Some wetland plants are, of course, stressed by salinity in laboratory experiments. There are, however, no field-based experimental results demonstrating that fresh, brackish, or salt marsh plants are killed or, if killed, that a replacement wetland plant community more tolerant of salt does not take its place. University scientists advising the State on restoration issues concluded that: "To our knowledge, no data is currently available that relates salinity reduction with reduction in land loss" (p. 8.12, Visser et al. 2003). In other words, a permanent loss of wetland area is not indicated by saltier water. Furthermore, several Louisiana estuaries show no significant change in salinity over the last several hundred years compared to the era of recent high land loss (Parsons et al. 1999). The variability in estuarine salinity over decades is related to the offshore influence of a variable Mississippi River discharge and is not a permanent change in salinity, except in a few specific local situations (Wiseman et al. 1990). The 200year record of Mississippi River discharge indicates variation in flow, but not a lasting change, whereas the discharge from the 1950s to 2000 is above average (Poore et al. 2006). Finally, local precipitation (and local stream discharge) has increased in the last 150 years, which would tend to freshen up the estuaries.

These two river diversions are meant to control estuarine salinity, but fluctuating salinities are a signature attribute of estuaries. A further question, then, is "Is the control of estuarine salinity, being confused with ecosystem resilience?" Hollings, one of the foundation thinkers behind what is called "Adaptive Management," said: "Natural resource management should strive to retain critical types and ranges of natural variation in ecosystems. That is, management should facilitate existing processes and variabilities rather than changing or controlling them. By so doing, ecosystem resilience and the organizing processes and structures of ecosystems will be maintained, thus better serving not only the natural functions and species diversity of those systems but also the long-term (although not necessarily short-term) interests of humanity" (Hollings and
Meffe 1996). Will controlling estuarine salinity with diversions restore or conserve more wetlands than if the diversion is not built? There are no data demonstrating that one choice is better than the other, but the diversions are built on the assumption that salinity control is essential to mitigate wetland loss. Is this a wise assumption? Is it sufficient reason to expend $\$ 100+$ million?

\section{Sediments}

Although the legal authority for building diversions is invested in salinity control, the widely accepted assumption is that introducing sediments to marshes is the main purpose of diversions, even though the solid material in most deltaic wetland soils is organic matter, not inorganic material (see previous discussion). Nevertheless, river diversions have been built to bring inorganic sediments into coastal wetlands to add to the soil volume. Snedden et al. (2007) determined that the inorganic sediments from the Caernarvon diversion becoming part of wetland soils traveled no more than $6 \mathrm{~km}$ from the diversion outfall. They calculated that even if all of the sediments in the diverted water were trapped, this amount would be insufficient to offset the relative rise in sea level. Hurricanes, in contrast, bring in 200 times more inorganic sediment to the entire coast and distribute these sediments democratically, albeit, episodically (Turner et al. 2006a).

Even more surprising is that there are no available scientifically based estimates of land gain or loss for the area in the path of these diversion or any other diversion. Several hundred million dollars have been spent and there is no professionally developed estimate of land gains and losses resulting from any diversion. Some questions that might reasonably be asked are: (1) what is the capacity for land building if all available sediment in the river were diverted to build land? and (2) what can be restored with the money available using other methods?

Winslow (2006) assessed how much sediment could be diverted and its potential to build land at conference focused on river diversions. Winslow, who works for an engineering consulting firm, assumed that the main river channel must remain useful for navigation and that it would be possible to capture $40 \%$ of the excess flow above $7,080 \mathrm{~m}^{3} \mathrm{~s}^{1}(250,000 \mathrm{cfs})$. He estimated that a diversion would be able to operate for less than $30 \%$ of the time. At this rate, and assuming 35\% retention of sediments, he estimated that there is the possibility of a land building rate of $6.4 \mathrm{~km}^{2}$ year ${ }^{-1}$. Building the engineering structures, however, would create $476 \mathrm{~km}^{2}$ of open water so that it would take 40 years before there was a net gain in land and another 617 years to restore an equivalent amount of land lost from the 1930s to 1990. An underlying assumption in this estimate of potential net land gain after 40 years is that 
there is no additional land loss elsewhere because of the sediment diverted to the new location. This project-specific estimate of new land is 2.6 times higher than the 7,000 years of land gain on this coast - by diverting only part of the river's flow. No one has yet explained, to my knowledge, how it is possible to exceed the historic land-building rate of the past 7,000 years (for the whole coast) using only part of the river's discharge.

The costs for building and maintaining such a megadiversion remain undefined, but will clearly be expensive. Here is one estimate: The cost per area created for existing diversions is inversely related to the size of the project (either dollars or amount of diverted water). A project creating a hoped-for $6.4 \mathrm{~km}^{2}$ year ${ }^{-1}$ would cost around $\$ 50$ to 100 million $\mathrm{km}^{-2}$ (2006 dollars; Turner and Boyer 1997), equal to $\$ 12$ to 25 billion for construction, and additional annual operational and maintenance costs.

\section{Nutrients}

Mississippi River diversions bring water to wetlands that had a low nutrient content until the expansion of Europeanstyle farming in the Mississippi River watershed in the 1800s (Broussard and Turner 2009). This means that the wetlands receiving overbank flooding before the $1800 \mathrm{~s}$ were ogliotrophic wetlands. The concentration of nitrate, and probably phosphorus, increased three- to five-fold between the early 1900s and the 1990s (Turner et al. 2007b). Nutrient enrichment of coastal wetlands, in general, results in higher aboveground standing biomass (Morris 1991). This may seem like a good thing if the goal is to increase aboveground plant biomass, but not if the goal is to increase the accumulation of soil organic matter. Here are some reasons why: Most plant production by emergent coastal marshes occurs belowground. This belowground production, all of it organic material, is the majority of material sustaining marshes as sea level rises, thus preventing excessive flooding, eventual plant death, and habitat loss. Results from short-term experiments demonstrate that root and rhizome biomass and carbon accumulation is reduced with nutrient enrichment (Table 3). Results from a 30-year experiment in salt marshes in Massachusetts also show that eutrophication does not increase organic matter accumulation belowground, but that it does weaken soil strength and causes a significant loss in marsh elevation equivalent to about half the average global sea level rise rates (Turner et al. 2009). The erosive influence of storms is more likely if there are fewer roots and rhizomes and diminished soil strength. In sum, sustaining and restoring coastal emergent marshes is more likely if they receive less, not more, nutrient loading.

An example of the chronic effects of nutrient additions may be what happened in 2005 when Hurricanes Katrina and Rita landed on the northern Gulf of Mexico coastline. Barras (2006) estimated that the area of coastal land declined by $513 \mathrm{~km}^{2}$ in the first year after hurricanes Katrina and Rita. At least half of this was in the Breton Sound estuary receiving the Caernarvon diversion. The northerly path of Hurricane Katrina crossed the area receiving the Caernarvon diversion water, and also a reference area to the east. A levee prevents the eastward flow of the diversion water into this reference area. Land loss was high where diverted Mississippi River water flowed south/southwest, but not in the reference marsh, except at Delacroix where there is an opening that allows some water to move from west to east (Fig. 4). Two smaller diversions, Naomi and West Pt. a la Hache, have land-loss patterns centered near, not far, from where these diversions enter the estuary. A hypothesis that the diverted water has the effect of making the marsh more resistant to hurricane impacts is contradicted by these results. There may be explanations for this unexpected outcome, but it seems like this is an important issue, especially in consideration of the long-term and expensive commitment made for these diversions and much larger diversions under consideration. The lack of a peer-reviewed analysis of how diversions alter hurricane impacts on land-to-water conversions leaves management with a shallow basis to justify important assumptions.

In conclusion, the present river diversions are expensive, have an unproven impact on wetland restoration, and may even lead to more wetland loss. If these efforts become successful, they are unlikely to restore the coast within centuries. Significant questions about the effectiveness of existing diversions remain that could have been addressed before they were built, which I think should be addressed before more are built.

\section{The Acceptance of Either the KBWV or IBWV has Meaningful Consequences}

The history of Louisiana's coastal land management is the acceptance of the KBWV. With the benefit of hindsight I conclude that this has been a problem for management done for narrowly defined goals of private entities or by the wellintentioned public entities backed by nongovernmental public-interest groups. The various land use interventions in coastal Louisiana were (and are still) based on a series of assumptions that have their individual and collective risks of being either incorrect or trivial. There are also risks for unidentified assumptions and for the interactions of assumptions producing new unidentified risks. The development of agricultural impoundments did not anticipate acid sulfate soils or the levee failures leading to their demise. The widespread use of water control structures may 
Table 3 Changes resulting from nutrient additions to freshwater marsh and saltwater marsh soil ecosystems

\begin{tabular}{|c|c|c|c|}
\hline Parameter & $\begin{array}{l}\text { Fresh marsh } \\
\text { (FM) }\end{array}$ & $\begin{array}{l}\text { Salt marsh } \\
\text { (SM) }\end{array}$ & Reference \\
\hline $\begin{array}{l}\text { Organic soil } \\
\text { accumulation }\end{array}$ & - & $\begin{array}{l}\text { Same or } \\
\text { lower }\end{array}$ & Morris and Bradley 1999 (SM); Turner et al. 2009 (SM); \\
\hline $\begin{array}{l}\text { Soil } \\
\text { decomposition }\end{array}$ & Faster & Faster & $\begin{array}{l}\text { Swarzenski et al. } 2008 \text { (FM); Bragazza et al. } 2006 \text { (FM); Mack et al. } 2004 \text { (FM); Eggelsmann } \\
\text { 1976; Harris et al. } 1962 \text { (FM); Laursen } 2004 \text { (FM) }\end{array}$ \\
\hline Root biomass & Lower & Lower & Darby and Turner 2008a, b; Valiela et al. 1976 (SM); Holm 2006 (FM) \\
\hline Soil Strength & Lower & Lower & Swarzenski et al. 2008 (FM); Turner et al. 2009 (SM) \\
\hline Elevation change & - & $\begin{array}{l}\text { Same or } \\
\text { lower }\end{array}$ & Turner et al. 2009 (SM); Franzen 2006 (FM); Eggelsmann 1976; Harris et al. 1962 \\
\hline
\end{tabular}

$F M$ fresh marsh, $S M$ salt marsh

have temporarily satisfied a desire to create waterfowl habitat and resulted in wetland loss. The indirect effects of dredging wetlands on wetland loss were presumed inconsequential because: (1) these impacts were not recognized, because wetlands were considered wastelands, or (2) their loss was a necessary consequence of fulfilling a perceived larger societal need. Society learned about the potential impacts of each of these interventions only after damage occurred and not before or during their implementations. Louisiana's coastal restoration efforts, even if $100 \%$ successful, are insufficient to redress these damages and have significant, and perhaps compromising, assumptions that may cause additional land loss as wetlands become impounded or semi-impounded by the levees. The proposed hurricane flood protection levees, if built, are poised to become the largest intervention in wetland management, ever. The area of these 4- to 5-m high levees will, like the much smaller spoil bank levees and marsh management levees, have an unavoidable negative impact on wetland habitat.

One factor contributing to why the IBWV is avoided may be because of the scale of the Louisiana restoration effort. It is simply harder to effectively raise questions within a large bureaucracy than in a small one. Thus, increasing the size of either the restoration program or adding the proposed flood protection program will be a significant barrier to adopting the more flexible and inclusive IBWV, especially within the context of urgency to "do something, do anything" that accompanies citizen interests in avoiding hurricane damages. In that context, advocating patience and a few small projects is not considered a particularly strong virtue by local governments. Less dramatic improvements, however, can have a demonstrable effect in the long run. Further, the cumulative significance of a small increase in management insights could have had a large impact on the cumulative loss rates.

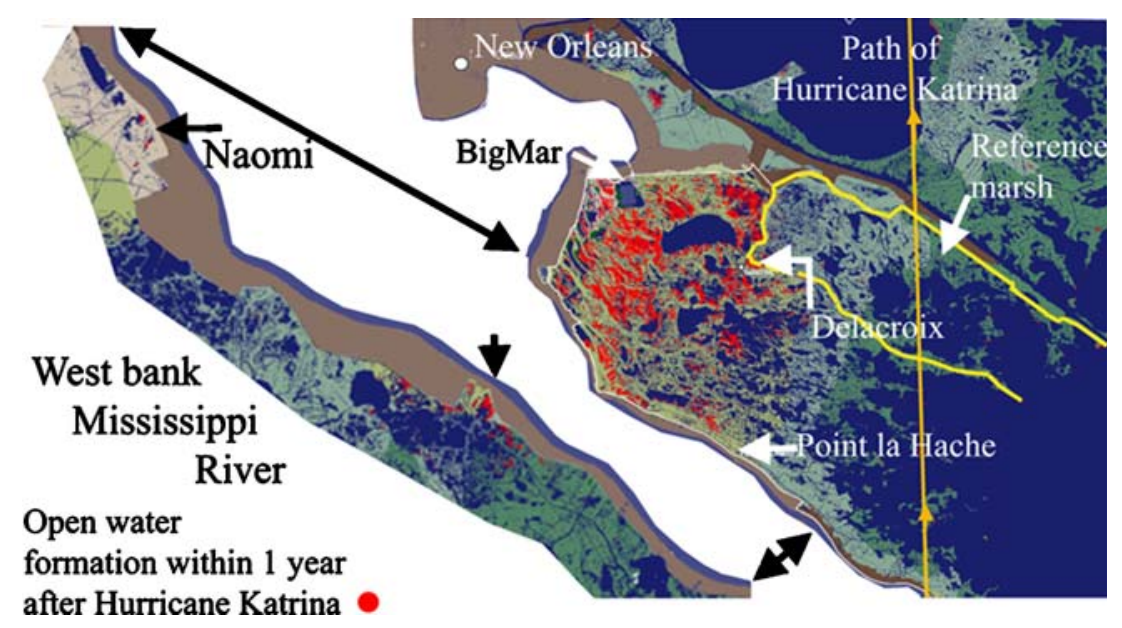

Fig. 4 Land loss (red) occurring within a year after hurricanes Katrina and Rita (2005; hurricane Katrina path is the orange line) in the path of the water flowing from three diversions, as determined by Barras (2006). The largest panel (right) is the flow path of the Caernarvon diversion, which enters the failed Big Mar agricultural pond, and then southward. The reference area, bounded by a natural levee ridge on the east is outlined in yellow. The smaller panel is an expanded view of land loss on the west bank near the Naomi and the West Pt. a la Hache diversions. Note that the only land loss on the west bank is centered near these two relatively small diversions 
For example, if the annual land-loss rates (calculated in Turner 1997) were lowered by $1 \%$ annually, with each year accumulating an additional 1\% reduction each year, then there would have been a $66 \%$ cumulative reduction in the area of land lost by 1990 .

\section{Adaptive Management}

A signature indicator of the prevalence of the KBWV is the undeniable and striking absence of effective monitoring and adaptive management in restoration (Ralph and Poole 2003; Bernhardt et al. 2005). This situation reveals a resistance to: (1) effective monitoring of project design, (2) implementation and assessment of post-construction developments in meaningful ways, (3) consideration of alternative outcomes in the beginning, including project failure, (4) intellectual audits, and (5) introduction of new information. The absence of the IBWV in this case jeopardizes opportunities to reduce financial waste, raise confidence in agency competency, and it may result in more wetland loss. Ralph and Poole (2003) said "Contemporary approaches to adaptive management preclude iterative, self-correcting management approaches by promising, but failing to implement, adequate and integrated monitoring programs." (p. 244). If restoration efforts actively embraced the IBWV, then monitoring is independent to better close the feedback loop, questions arising are used to direct the restoration, a strong experimental framework is included, the design phase is well-ventilated, and the capabilities to monitor would drive the definition of goals - not the other way around. If goals are not monitored, then how else is "success" quantified and compared to some metric of success? If the IBWV is adopted, then monitoring program goals and metrics are developed before determining what management might be appropriate, before agreeing on management, and before specific management actions are started. In this way, management can optimize results and reduce the opportunities to do irrevocable harm when something unexpected happens-and unexpected things will happen in complex systems.

\section{Complex or Complicated}

Compared to the KBWV, adopting the IBWV offers a strong advantage when addressing complex problems. Complicated problems can be broken down into understandable parts, and the results might be modeled and applied to other areas. Complex problems, however, are more resistant to inquiry because of, for example, incomplete information and inadequate insights about nonlinear interactions. Applying the results from systems assumed to be merely complicated, when they are actually complex, may result in unforeseen additional problems if the heterogeneous environmental template is viewed as homogenous. A sign of intellectual fatigue in this regard is the flattening of complexity to simplistic assertions about coastal processes, and the submission of quantitative and critical inquiry under the pressure to do something (now!) about an urgent need.

\section{Models}

Models are a potentially useful means to overcome some of the problems managing both complicated and complex systems. But modeling conducted and received within either a KBWV or IBWV will have very different levels of certainty and acceptance. If the model is assumed to faithfully predict the future, then there may be little interest in defining the bounds of expectation. Even if these bounds of expectation are identified, the prediction may be useless in the long term. If the ecosystem model of an undisturbed estuary, for example, is based on the average conditions, perhaps because of limited field data or foregoing data incorporation, then model predictions may give comforting, but erroneous, results when novel conditions arise and interact with other factors. For example, a 20-year record of monthly precipitation may be useful to predict estuarine salinity-until there is a hurricane. In this case, the prediction of estuarine salinity may be accurate $99 \%$ of the time, but not accumulate during the $1 \%$ of the time during which a surge of saltwater is trapped behind a flood protection levee, causing plant death. But, if the model is assumed to have significant unknowns (the IBWV), then it will have wide bounds of expectation, perhaps demonstrating the model's heuristic value, but undermining confidence applying it for management purposes.

Pilkey and Pilkey-Jarvis (2007) make the point that some models are, unfortunately, sometimes misused to stifle discussion of alternative discussion by creating the aura of a misplaced level of certainty to create a political advantage that suppresses debate, especially if the model is opaque. This is not to say that models are inherently unconstructive - they are not. The climate change models, for example, are well ventilated by an inclusive participant list, alternative views are sought, and there is an abundance of data to test the models (Elzinga 1997). It is the context in which the models are developed and discussed that makes the global climate change models useful rather than a hindrance, and that context is a key to the acceptance of the IBWV - to create an accepted and useful network of communication and information exchange that illuminates the areas of risks inherent in accepting different levels of certainty represented in models, how to adapt to new information, and to accurately identify complex system behaviors. 


\section{Some Simple Goals}

Below are a few simple goals that are fostered by adoption of the IBWV and that may help avoid potentially fatal flaws of logic, administration lapses, and financial waste.

1. Assume that key pieces of information are missing and may not be revealed (ever)

2. Because of the collective and respected ignorance, be flexible in how to develop, evaluate, and apply new information and perspectives; learn how to create the context for that situation

3. Include many small steps that are addressed in multiple ways

4. Let data trump concepts, not the reverse. If "the bigger, the better" is the operating model, then the model is likely to be superficially abstract (this is not to dispute the need for hierarchy or a division of labor)

5. Assume that surprises will occur

6. Develop exit strategies, including how to reverse interventions

7. Do no harm; do not implement plans that will be irreversible if they go awry; if irreversible outcomes are anticipated, then start with the smallest plans, not the largest ones

Acknowledgments This manuscript benefited from conversations and work with many colleagues inside and outside of academia, and with students over the years, and from the comments of three anonymous reviewers. I am also thankful for time spent with the Land Institute and C. Swarzenski, and for the enthusiasm of nonscientists who thoughtfully nurture efforts to make things better. Mike Weinstein extended the invitation to participate in a Future International Sustainability/Integrated Coastal Zone Management/Ecosystem Rehabilitation Symposium at the 2008 Restore America's Estuary meeting. Support was provided by the NOAA Coastal Ocean Program MULTISTRESS Award No. NA16OP2670 to Louisiana State University.

Conflict of Interest I have no financial relationship with the organization that sponsored the research. I have full control of all primary data and agree to allow the journal to review the data if requested. There are no potential conflicts in the use of the data or financial conflicts.

\section{References}

Allen, J.R.L., and M.G. Fulford. 1992. Romano- British and later geoarchaeology at Oldbury Flats: Reclamation and settlement on the changeable coast of the Severn Estuary. Archaeological Journal 149: 82-123.

Anon. 1995. Coastal Wetlands planning, protection, and restoration act: summary of priority lists 1-4. CWPPRA report series No. 1 . Baton Rouge: Louisiana Department of Natural Resources.

Anonymous 2006. On Reintroducing Riverine Processes in the Mississippi Delta Region. Proceedings Crest Symposium 18 April, 2006. http://www.gulfcrest.org/Meetings/April 2006/ Diversions_meeting_report.pdf. Accessed 16 Jan. 2009.
Barras, J.A. 2006. Land area change in coastal Louisiana after the 2005 hurricanes - a series of three maps: US Geological Survey Open-File Report 2006-1274.

Barber, B. 1961. Resistance by scientists to scientific discovery. Science 134: 597-602.

Bass, A., and R.E. Turner. 1997. Relationships between salt marsh loss and dredged canals in three south Louisiana estuaries. Journal of Coastal Research 13: 895-903.

Baumann, R.H., and R.E. Turner. 1990. Direct impacts of outer continental shelf activities on wetland loss in the central Gulf of Mexico. Environmental Geology and Water Resources 15: 189198.

Bernhardt, E., et al. 2005. Synthesizing U.S. river restoration efforts. Science 308: 636-637.

Berry, W. 1982. Quoted from a letter to Wes Jackson, 1982. http:// www.landinstitute.org/vnews/display.v/ART/2004/10/03/ 42c0db19e37f4. Accessed 10 May 2009.

Boyer, M.E. 1997. The effect of long-term marsh management on land-loss rates in coastal Louisiana. Environmental Management 21: $97-104$.

Bragazza, L., C. Freeman, T. Jones, H. Rydin, J. Limpens, N. Fenner, T. Ellis, R. Gerdol, M. Hájek, T. Hájek, P. Lacumin, L. Kutnar, and T. Tahvanainen. 2006. Atmospheric nitrogen deposition promotes carbon loss from peat bogs. Proceedings of the National Academy of Sciences of the United States of America 103: 19386-19389.

Britsch, L.D., and J.B. Dunbar. 1993. Land-loss rates: Louisiana Coastal Plain. Journal of Coastal Research 9: 324-338.

Broussard, W., and R.E. Turner. 2009. A century of changing land use and water quality relationships in the continental US. Frontiers in Ecology and the Environment 7(6): 302-307. doi:10.1890/ 080085.

Chabreck, R.H. 1972. Vegetation, water and soil characteristics of the Louisiana coastal region. Louisiana State University Agricultural Exp. Station Bulletin 664: 72.

Chabrek, R.H., and A.W. Palmisano. 1973. The effects of Hurricane Camille on the marshes of the Mississippi River delta. Ecology 54: $1118-1123$.

Darby, F.A., and R.E. Turner. 2008a. Effects of eutrophication to salt marsh roots, rhizomes, and soils. Marine Ecology Progress Series 363: 63-70.

Darby, F.A., and R.E. Turner. 2008b. Below- and aboveground biomass of Spartina alterniflora: Response to nutrient addition in a Louisiana salt marsh. Estuaries and Coasts 31: 326-334.

Davis, D. W. 1973. Louisiana canals and their influence on wetland development. Ph.D. Dissertation. Baton Rouge: Louisiana State University, $199 \mathrm{pp}$

Eggelsmann, R. 1976. Peat consumption under influence of climate, soil condition, and utilization. Proceedings International Peat Congress 1: 233-247. International Peat Society Poznan, Poland.

Elzinga, A. 1997. From Arrhenius to megascience: Interplay between science and public decision making. Ambio 26: 72-80.

Finlayson, A.C. 1994. Fishing for truth: A sociological analysis of northern cod stock assessment from 1977-1990. St. John's: Institute of Social and Economic Research Memorial University of Newfoundland. $176 \mathrm{pp}$.

Fisk, H.N., E. McFarlan Jr., C.R. Kolb, and L.J. Wilbert Jr. 1954. Sedimentary framework of the modern Mississippi delta. Journal of Sedimentary Petrology 24: 76-99.

Franzen, L.G. 2006. Increased decomposition of subsurface peat in Swedish raised bogs: Are temperate peatlands still net sinks of carbon? Mires and Peat 3: 1-16.

Frazier, D.E. 1967. Recent deltaic deposits of the Mississippi River, their development and chronology. Transactions Gulf Coast Association of Geological Societies 17: 287-315. 
Harris, C.I., H.T. Erickson, N.K. Ellis, and J.E. Larson. 1962. Waterlevel control in organic soil, as related to subsidence rate, crop yield, and response to nitrogen. Soil Science 94: 158-161.

Harrison, R.W., and W.M. Kollmorgen. 1947. Past and prospective drainage reclamations in coastal marshlands of the Mississippi River Delta. Journal of Land and Public Utility Economics 23: 297-320.

Hollings, C.S., and G.K. Meffe. 1996. Command and control and the pathology of natural resource management. Conservation Biology 10: $328-337$.

Holm, G.O. Jr. 2006. Nutrient constrains on plant community production and organic matter accumulation of subtropical floating marshes. Dissertation, Baton Rouge, LA: Louisiana State University.

Kesel, R.H. 1988. The decline in the suspended load of the lower Mississippi River and its influence on adjacent wetlands. Environmental Geology and Water Sciences 11: 271-281.

Kuhn, T.S. 1987. The structure of scientific revolutions. Chicago: Univ. Chicago Press.

Laursen, K. R. 2004. The effects of nutrient enrichment on the decomposition of belowground organic matter in a Sagittaria lancifolia- dominated ogliohaline marsh. Thesis, Baton Rouge: Louisiana State University.

Mack, M.C., E.A.G. Schuur, M.S. Bret-Harte, R. Shaver, and S. Chaplin III. 2004. Ecosystem carbon storage in arctic tundra reduced by long-term nutrient fertilization. Nature 431: 440-443.

Meade, R.H., and R.S. Parker. 1984. Sediments in rivers of the United States. National Water Supply Summary US. Washington, D. C.: US Government Printing Office. Geological Survey WaterSupply Paper 2275.

Morris, J.T. 1991. Effects of nitrogen loading on wetland ecosystems with particular reference to atmospheric deposition. Ann Rev Ecol Systemat 22: 257-279.

Morris, J.T., and P. Bradley. 1999. Effects of nutrient loading on the carbon balance of coastal wetland environments. Limnology and Oceanography 44: 699-702.

Parsons, M.L., Q. Dortch, R.E. Turner, and N.N. Rabalais. 1999. Salinity history of coastal marshes reconstructed from diatom remains. Estuaries 22: 1078-1089.

Okey, C.W. 1918. The wet lands of southern Louisiana and their drainage. USDA Bull 652: 67.

Peterson, B.J. 1993. The costs and benefits of collaborative research. Estuaries 4: 913-918.

Pilkey, O.H., and L. Pilkey-Jarvis. 2007. Useless arithmetic: why environmental scientists can't predict the future, 230. New York: Columbia University Press.

Poore, R. Z., J. Darling, H. J. Dowsett, and L. Wright. 2006. Variations in river flow to the Gulf of Mexico: Implications for paleoenvironmental studies of Gulf of Mexico marine sediments. http://pubs.usgs.gov/bul/b2187/contents.html.

Ralph, S.C., and G.C. Poole. 2003. Chapter 9. Putting monitoring first: designing accountable ecosystem restoration and management plans. In Restoration of puget sound rivers, ed. D.R. Montgomery, S. Bolton, D.B. Booth, and L. Wall, 226-247. Seattle: University of Washington Press.

Roberts, H.H., J.M. Coleman, S.J. Bentley, and N. Walker. 2003. An embryonic major delta lobe: A new generation of delta studies in the Atchafalaya-Wax Lake delta system. Gulf Coast Association of Geological Societies Transactions 53: 690-703.

Scaife, W.W., R.E. Turner, and R. Costanza. 1983. Recent land loss and canal impacts in coastal Louisiana. Environmental Management 7: 433-442.

Seed, R. B. et al. 2006. Investigation of the Performance of the New Orleans Flood Protection System in Hurricane Katrina on August 29, 2005. Independent Levee Investigation Team: Final Report Available at: http://works.bepress.com/rmoss/17.
Senge, P. B., Smith, N., Kruschwitz, J., Laur, and S. Schley. 2008. The Necessary Revolution: How Individuals and Organizations are Working Together to Create a Sustainable World. Doubleday.

Snedden, G., J.E. Cable, C. Swarzenski, and E.M. Swenson. 2007. Sediment discharge into a subsiding Louisiana deltaic estuary through a Mississippi River diversion. Estuarine Coastal and Shelf Science 71: 181-193.

Stanley, D.J., and A.G. Warne. 1994. Worldwide initiation of holocene marine deltas by deceleration of sea-level rise. Science 265: 228 231.

Swarzenski, C.M., T.W. Doyle, B. Fry, and T.G. Hargis. 2008. Biogeochemical response of organic-rich freshwater marshes in the Louisiana delta plain to chronic river water influx. Biogeochemistry 90: 49-63.

Swenson, E.M., and R.E. Turner. 1987. Spoil banks: Effects on a coastal marsh water level regime. Estuarine Coastal and Shelf Science 24: 599-609.

Turner, R.E. 1991. Tide gage records, water level rise and subsidence in the northern Gulf of Mexico. Estuaries 14: 139-147.

Turner, R.E. 1997. Wetland loss in the northern Gulf of Mexico: Multiple working hypotheses. Estuaries 20: 1-13.

Turner, R.E. 2004. Coastal wetland subsidence arising from local hydrologic manipulations. Estuaries 27: 265-273.

Turner, R.E. 2006. Will lowering estuarine salinity increase Gulf of Mexico oyster landings? Estuaries and Coasts 29: 345-352.

Turner, R.E. 2007. Geomorphology and perception in New Orleans after Iberville and Bienville. Technology in Society 29: 227-238.

Turner, R.E. 2008. Comments on Buzan et al. "Positive relationships between freshwater inflow and oyster abundance in Galveston Bay, Texas". Estuaries and Coasts 32: 1559-2731. doi:10.1007/ s12237-008-9113-0.

Turner, R.E., and M.E. Boyer. 1997. Mississippi River diversions, coastal wetland restoration/creation and an economy of scale. Ecological Engineering 8: 117-128.

Turner, R.E., and B. Streever. 2002. Approaches to coastal wetland restoration: Northern Gulf of Mexico. The Hague: SPB. 147pp.

Turner, R.E., and N.N. Rabalais. 2003. Linking landscape and water quality in the Mississippi River Basin for 200 years. BioScience 53: $563-572$.

Turner, R.E., J.W. Day Jr., and J.G. Gosselink. 1989. Weirs and their effects in coastal wetlands (exclusive of fisheries). Proc. Louisiana Geological Survey/US Fish Wildlife Serv. Marsh Management Symposium Biological Report 89(22): 151-163.

Turner, R.E., E.M. Swenson, and C.S. Milan. 2001. Organic and inorganic contributions to vertical accretion in salt marsh sediments. In Concepts and Controversies in Tidal Marsh Ecology, ed. M. Weinstein and K. Kreeger, 583-595. Dordrecht: Kluwer.

Turner, R.E., J.J. Baustian, E.M. Swenson, and J.S. Spicer. $2006 a$. Wetland sedimentation from Hurricanes Katrina and Rita. Science 314: 449-452.

Turner, R.E., C.S. Milan, and E.M. Swenson. 2006b. Recent volumetric changes in salt marsh soils. Estuarine and Coastal Shelf Science 69: 352-359.

Turner, R.E., E.M. Swenson, C.S. Milan, and J.M. Lee. 2007a. Hurricane signals in salt marsh sediments: Inorganic sources and soil volume. Limnology and Oceanography 52: 1231-1238.

Turner, R.E., N.N. Rabalais, R.B. Alexander, G. McIsaac, and R.W. Howarth. 2007b. Characterization of nutrient and organic carbon and sediment loads and concentrations from the Mississippi River into the northern Gulf of Mexico. Estuaries and Coasts 30: 773-790.

Turner, R.E., B.L. Howes, J.M. Teal, C.S. Milan, E.M. Swenson, and D. Goehringer-Toner. 2009. Salt marshes and eutrophication: An unsustainable outcome. Limnology and Oceanography 54: 1634-1642.

U.S. Government Accountability Office. 2007. Coastal Wetlands: lessons learned from past efforts in Louisiana could help guide 
future restoration and protection. Washington, D.C: US Printing Office, GAO.

United States House of Representatives. 2006. Hurricane Katrina Report, A Failure of Initiative, Final Report of the House Select Bipartisan Committee to Investigate the Preparation and Response, Senate Investigation Documents. House Report 109-377. Union Calendar No. 205. http://katrina.house.gov/ Accessed November 7, 2006).

Valiela, I., J.M. Teal, and N.Y. Persson. 1976. Production dynamics of experimentally enriched salt marsh vegetation: Belowground biomass. Limnology and Oceanography 21: 245-252.

Visser, J.M., J. Callaway, D. Reed, G.D. Steyer, J. Suhayda, and E.M. Swenson. 2003. Wetland nourishment module. Chapter 8. In Coastal Louisiana Ecosystem Assessment and Ecosystem Resto- ration (CLEAR) Model of Louisiana Coastal Area (LCA) Comprehensive Ecosystem Restoration Plan. Vol. 1: Tasks 1-8, ed. R.R. Twilley. Baton Rouge: Coastal Restoration Division, Louisiana Department of Natural Resources.

Vitek, B., and W. Jackson (eds). 2008. The virtues of ignorance. Lexington: Univ. Press of Kentucky.

Winslow, K. 2006. The Third Delta conveyance channel (TDCC) project: feasibility assessment. In On Reintroducing Riverine Processes in the Mississippi Delta Region, Crest Symposium 18 April, 2006. http://www.gulfcrest.org/Meetings/April 2006/ Diversions_meeting_report.pdf. Accessed 16 Jan. 2009

Wiseman Jr., W.J., E.M. Swenson, and J. Power. 1990. Salinity trends in Louisiana estuaries. Estuaries 13: 265-271. 